\title{
Pengaruh Kinerja Hidraulik Kontrol Valve Setelah Overhaule Terhadap Governor Mesin Turbin Uap Pada PLTU (Media Group 1 x 15 Mw)
}

\author{
Pribadyo $^{1}$, Zulkifli Said ${ }^{2}$ \\ ${ }^{1}$ Jurusan Mesin, Fakultas Teknik, Universitas Teuku Umar, Meulaboh \\ ${ }^{2}$ Mahasiswa Jurusan Mesin, Fakultas Teknik Universitas Teuku Umar \\ Email: dyo_1806@yahoo.co.id
}

\begin{abstract}
Abstrak
PLTU di Desa Kuta Makmue Kecamatan Kuala Kabupaten Nagan Raya dengan kapasitas terpasang 1x15 MW beroperasi sejak tahun 2009 mengunakan Turbin tipe BBC NEW ALSTOM BD2EEQ2E38 yang diproduksi pada tahun 1970 tergolong dalam Sistem Manual Operasi, namun seiring dengan lamanya pengoperasian turbin dan bertambahnya jam operasional serta kendala teknis maupun non teknis yang dialami selama operasi mengakibatkan kinerja dari hidraulik kontrol valve berkurang dan mempengaruhi data karakteristik semula. Tujuan dari penelitian ini adalah mengkaji pengaruh kinerja control valve setelah overhaule terhadap governor pada turbin uap. Metode yang digunakan adalah studi pustaka dan studi lapangan yakni dengan meninjau langsung ke lapangan untuk pengakuratan data literature dan data lapangan yang menjadi objek dalam penelitian. Wawancara, yaitu menanyakan kepada orang-orang yang memahami tentang topik yang dikaji. Analisa data dilakukan guna mengetahui peroalan yang sebenarnya terjadi pada sistem yang dikaji selanjutnya dialkukan penanganan. Hasil penelitian dikatahui bahwa ukuran dimensi Bushing dan Sraight bar (Tuas valve lurus) mengalami keausan, keausan yang paling besar terdapat pada strainght bar hindraulik kontrol valve hingh pressure, perubahan nilai tersebut didapat setelah pengambilan nilai rata-rata dari komponen hidraulik. penanganan perbaikan dengan melakukan penambalan isi (Babit) pada sisi outside straingth bar yang terkikis, pembabitan tersebut dilakukan dengan menyamakan nilai rata-rata dari dimensi strainght bar.
\end{abstract}

Keywords: Governor, kontro; valve, overhauled an turbin uap

\section{PENDAHULUAN}

Dewasa ini pemerintah sedang menggalakkan program pengembangan sektor ketenagalistrikan yakni sebesar 35 ribu MW yang terbagi atas 10 ribu MW yang akan disuplai oleh pemerintah sedangkan sisanya sebesar 25 ribu MW akan dikelola oleh sektor swasta. Dimana wilayah sumatera merupakan salah satu prioritas uatama dalam pemenuhan sektor ketenaga listrikan. saat ini telah dibangun dan telah dioperasikan PLTU baik yang dibangun oleh pemerintah yakni PLTU dengan kapasitas 2 x 110 MW yang terletak di Desa Suak Puntong Kecamatan Kuala Pesisir Kabupaten Nagan Raya, sedangkan oleh pihak swasta juga telah dibangun dan dioperasikan PLTU dengan kapasitas 1 x 15 MW yang juga terletak di Kabupaten Nagan Raya tepatnya di Desa Kuta Makmue Kecamatan Kuala 


\section{Jurnal Mekanova}

Vol 4. No. 2, April 2018

ISSN : 2502-0498

PLTU di Desa Kuta Makmue Kecamatan Kuala Kabupaten Nagan Raya dengan kapasitas terpasang 1x15 MW beroperasi sejak tahun 2009 hingga sekarang. Keberadaannya sangat membantu pasokan listrik di kawasan pantai barat selatan Aceh, PLTU ini mengunakan Turbin tipe BBC NEW ALSTOM BD2EEQ2E38 yang diproduksi pada tahun 1970 dan tergolong dalam Sistem Manual Operasi. Pada turbin ini mengunakan sistem hidraulik kontrol valve dengan sistem pengaturan governor.

Awalnya sistem kontrol valve pada turbin dapat beroperasi sebgaimana mestinya sesuai dengan data karakteristik yang bersumber dari manual book, akan tetapi seiring dengan lamanya pengoperasian turbin tersebut dan bertambahnya jam operasional serta kendala teknis maupun non teknis yang dialami selama operasi mengakibatkan kinerja dari hidraulik kontrol valve berkurang dan mempengaruhi data karakteristik semula, maka berdasarkan uraian dan permasalahan diatas maka pengaruh sistem kerja kontrol valve setelah overhaule terhadap governor perlu dikaji.

\section{METODE PENELITIAN}

Penelitian ini dilakukan di PT. Energi Alamraya Semesta Desa Suka Makmue Kecamatan Kuala Kabupaten Nagan Raya. Penelitian ini mengunakan Metodologi Studi Literatur, yaitu dengan mengumpulkan data-data informasi yang mencakup PLTU secara keseluruhan dan secara khusus pada sistem hidraulik kontrol valve. Studi Lapangan, yaitu dengan meninjau langsung ke lapangan untuk pengakuratan data literature dan data lapangan yang menjadi objek dalam penelitian. Wawancara, yaitu menanyakan kepada orang-orang yang memahami tentang topik yang dikaji.

Setelah data-data yang berhubungan dengan penelitian diperoleh, selanjutnya dilakukan identifikasi permasalahan yang terjadi. Setelah didapat permaslahan selanjutnya permasalahan terebut di invetarisir untuk dianalisa dan dilakukan tahap penanganan selanjtnya. Diagram alir penelitian ditunjukkan pada gambar 3.1 sebagai berikut.

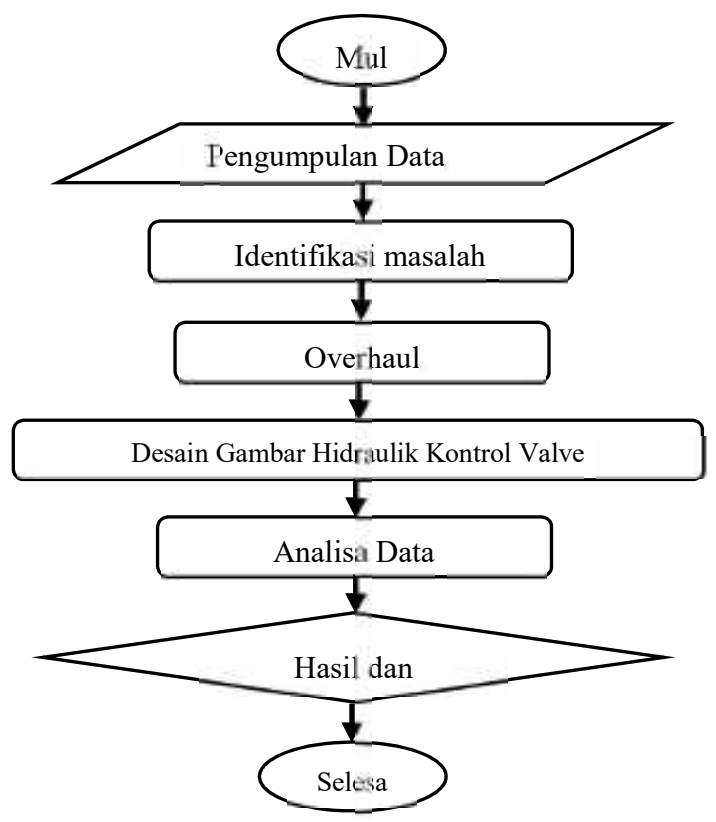

Gambar 3.1 Flow chat penulisan 
Jurnal Mekanova

Vol 4. No. 2, April 2018

ISSN : 2502-0498

\section{HASIL DAN PEMBAHASAN}

\section{- Hasil Data Awal}

Kinerja dari tiap-tiap kontrol valve Hingh Presure (HP), Intermediate Presure (IP) dan governor berdasarkan dari manual book adalah sebagai berikut:

Press Oil Dari 0.7 s/d 4.68

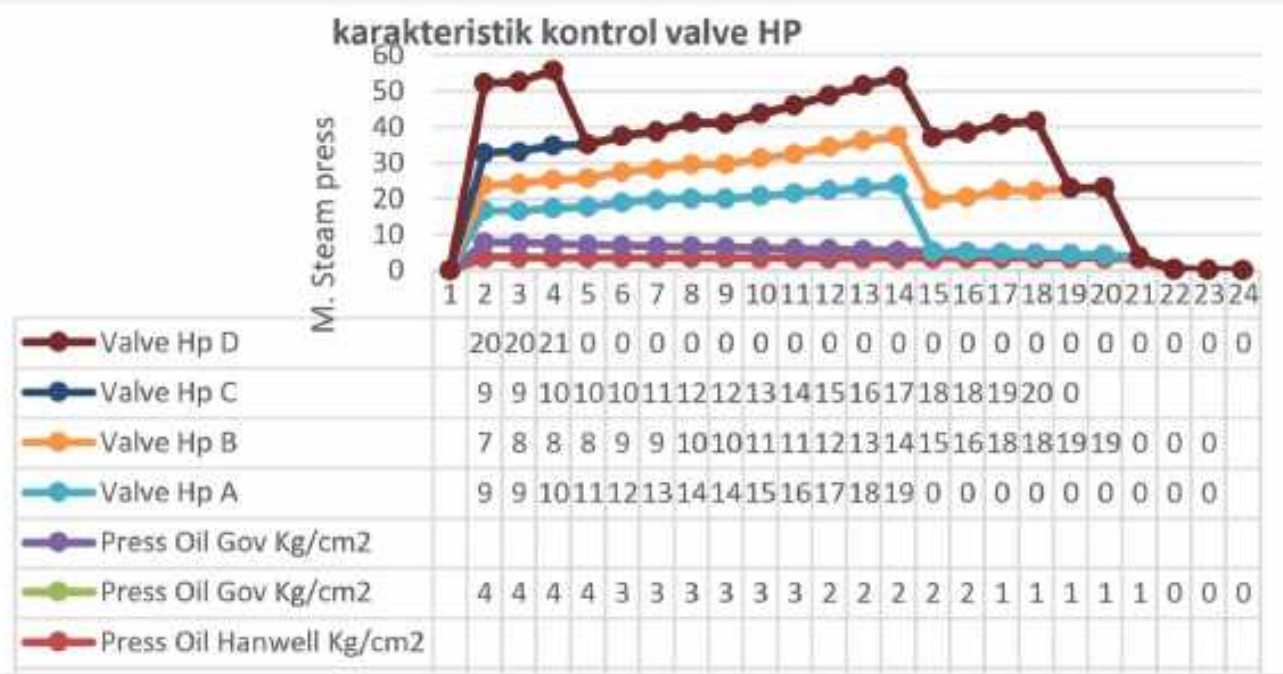

Grafik 4.1 Kinerja kontrol valve Hingh Presure (HP) berdasarkan presure oli governor dan press main steam

Sumber manual book jerman 1970

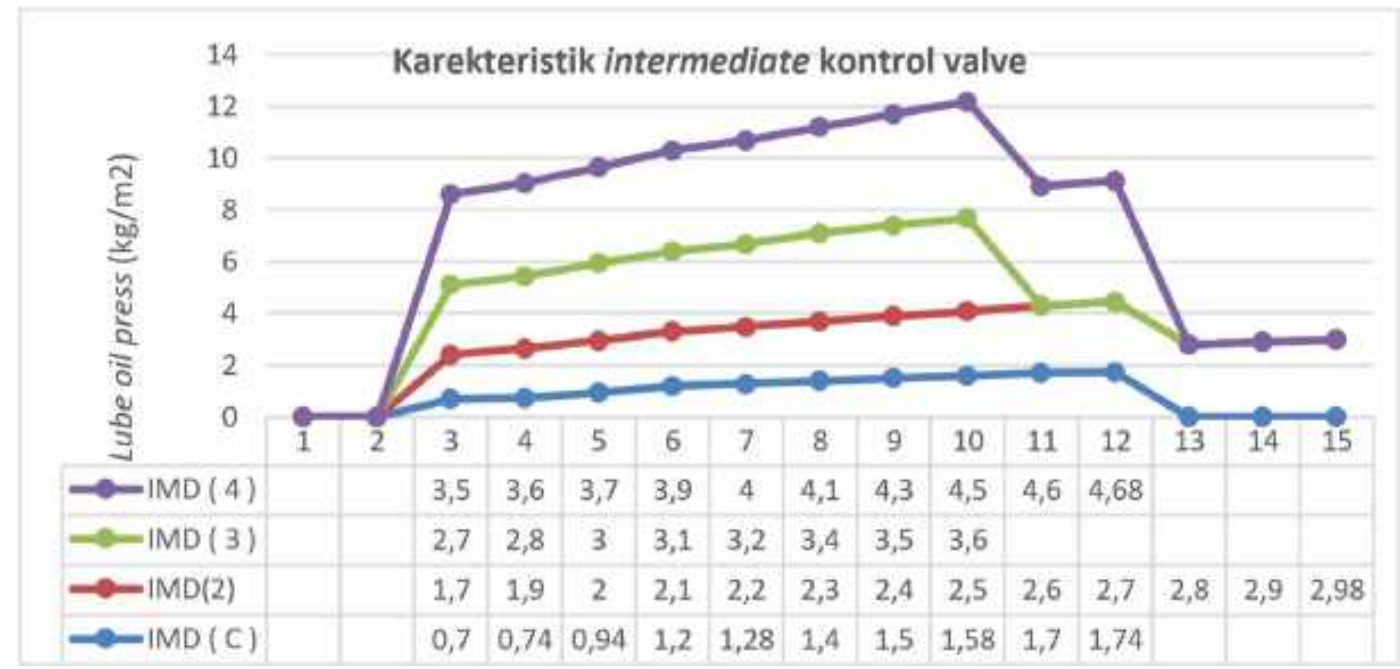

Garafik 4.2 Kinerja kontrol valve Intermediate Presure (IP)

Sumber: hand book, Jerman, 1970

\section{- Indentifikasi Masalah}

Berdasarkan data awal yang didapat serta dari hasil obsorvasi dilapangan ditemukan keganjilan dalam sistem operasional unit turbin, keganjilan tersebut ditemukan pada sisi 


\section{Jurnal Mekanova}

Vol 4. No. 2, April 2018

ISSN : 2502-0498

hidraulik kontrol valave Hingh Pressure yang C, dimana ditemukan kondisinya mengalami kebocoran di sisi dalam straigh bar serta busingnya.

Kebocoran tersebut diperkirakan terjadi karenakan gesekan antara komponen straingh bar dengan Bushing bar bagian dalam, karena selama beroperasi hindaulik kontrol valve terus bekerja naik-turun sesuai dengan tekana oli yang diterimanya, oleh karenanaya bagian yang saling bergesekan tersebut lebih cepat mengalami keausan.

\section{- Overhaule}

Setelah dilakukan analisa dari data-data yang diperoleh maka, untuk mengatasi permasalahan tersebut dilakukan perbaikan dan Overhaule. Overhaule dilakukan oleh PT. Nusantara Turbin dan Propulsi (NTP) selaku Vendor yang ditunjuk Perusahaan sebagai penanggug jawab atas pengerjaan Overhaule tersebut.

\section{- Desain Gambar}

Pendesainnan gambar dilakukan guna melengkapi dokumentasi dari hasil penangganan masalah yang telah dilakukan. Ukuran dimensi gambar diambil sesuai dengan ukuran dimensi komponen Strainght bar dan Bushing bar sebenarnya. (Berkas terlampir)

\section{- Hasil Analisa}

\section{- Hasil Analisa Komponen}

Berdasarkan dari hasil laporan kerja oleh PT. Nusantara Turbin \& Propulsi (NTP) selaku Vendor pelaksana Overhaule turbin pada bulan April 2014, bahwasanya ukuran dimensi Bushing dan Sraight bar (Tuas valve lurus) mengalami keausan, keausan yang paling besar terdapat pada strainght bar hindraulik kontrol valve hingh presure yang C (Gambar lampiran $4.1 \& 4.2$ ) perubahan nilai tersebut didapat setelah pengambilan nilai rata-rata dari komponen hidraulik tersebut.

Dari hasil nilai rata-rata tersebut maka dilakukan penanganan perbaikan dengan melakukan penambalan isi (Babit) pada sisi outside straingth bar yang terkikis, pembabitan tersebut dilakukan dengan menyamakan nilai rata-rata dari dimensi strainght bar tersebut.

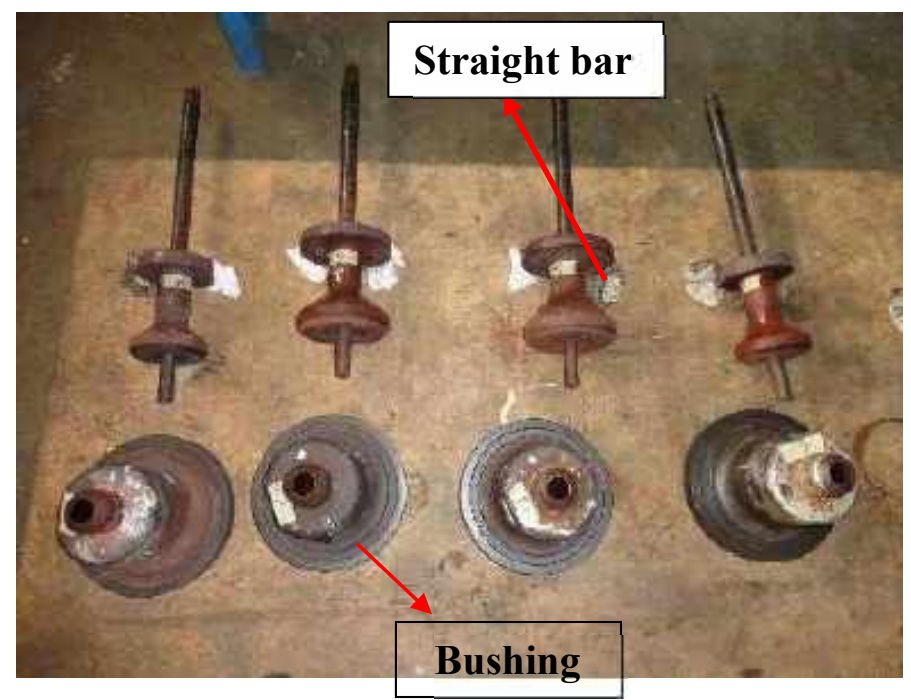

Gambar 4.3 Komponen hidraulik kontrol valve Sumber : PLTU media group 2014 
Jurnal Mekanova

Vol 4. No. 2, April 2018

ISSN : 2502-0498

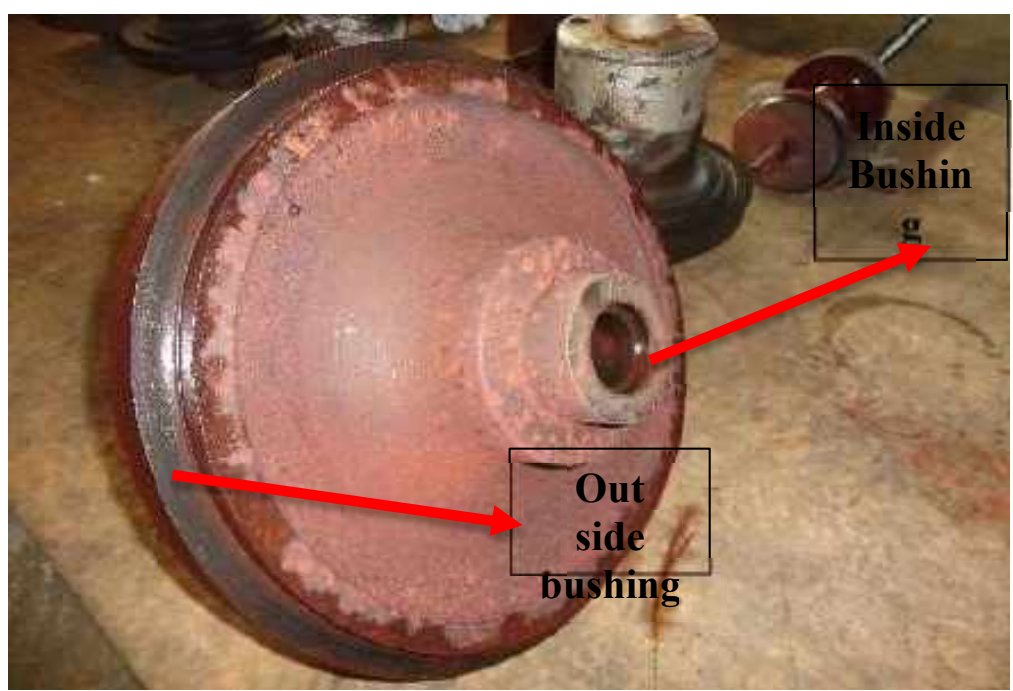

Gambar 4.4 Komponen Bushing hidraulik kontrol valve Sumber : PLTU media group 2014

\section{- Hasil Analisa Kinerja Kontrol Valve HP}

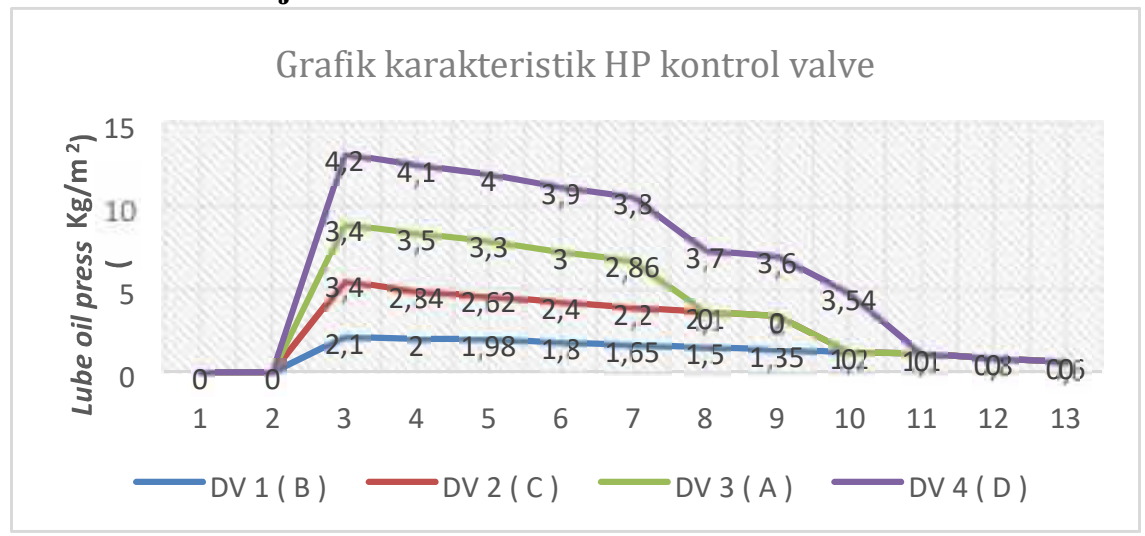

Grafik 4.5 Grafik karakteristik kontrol valve HP Sumber: Pltu Media Group 2014

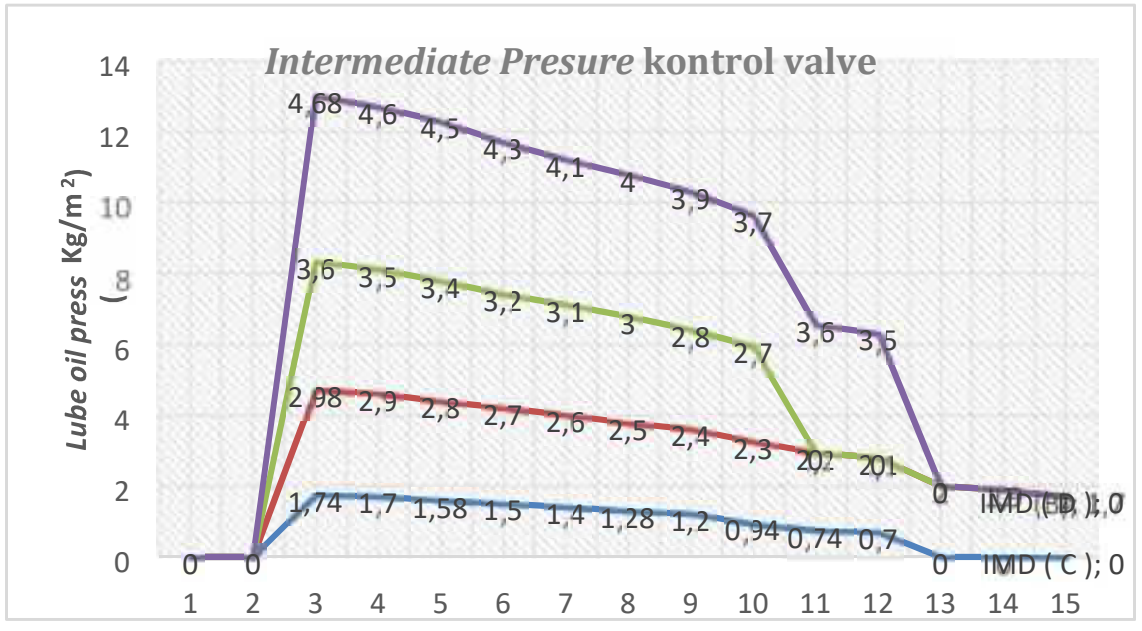

Grafik 4.6 Karakteristik kontrol valve IP 
Jurnal Mekanova

Vol 4. No. 2, April 2018

ISSN : 2502-0498

Sumber: Pltu Media Group 2014

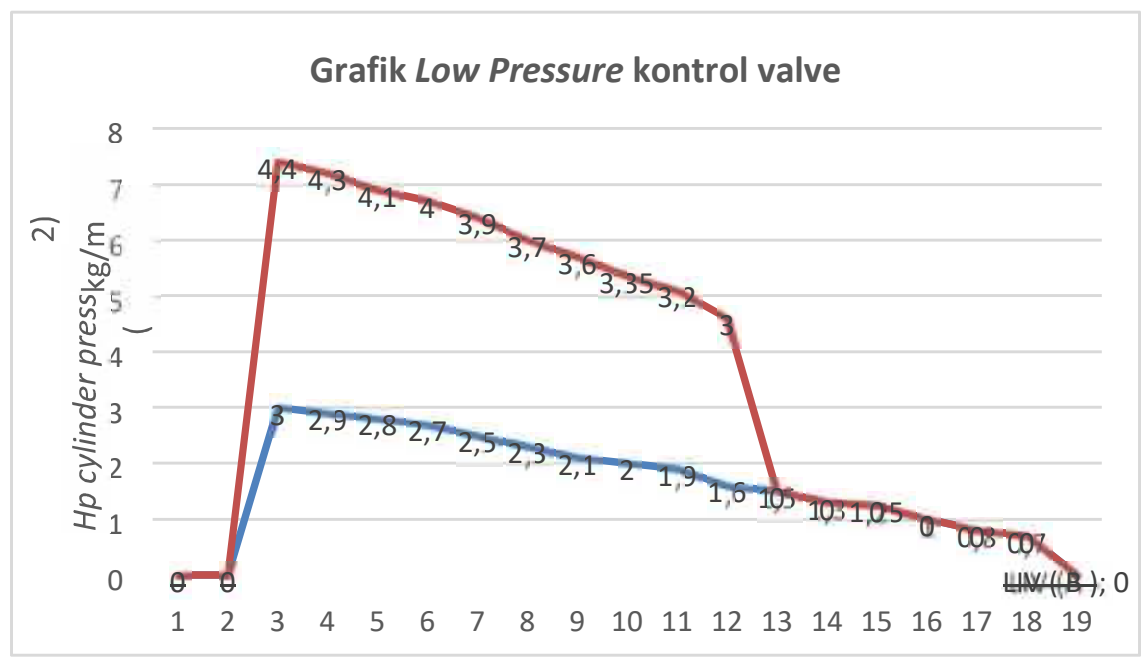

Grafik 4.7 Karakteristik kontrol valve LP Sumber:

Pltu Media Group 2014

\section{Pembahasan}

Setelah dianalisa berdasarkan data awal maka didapati bahwa kinerja dari hindaulik kontrol terhadap governor berubah, perubahan tersebut dapat dilihat dengan seksama melalui grafik 4.3, 4.4, dan 4.5 merupakan grafik kinerja hindraulik kontrol valve setelah dilakukan overhaule, nilai-nilai dari perubahan kinerja tersebut dapat dilihat pada tabel dan grafik kinerja keseluruhan dari hidraulik kontrol valve dibawah ini:

\begin{tabular}{|c|c|c|c|c|c|c|c|c|c|}
\hline $\mathrm{DV}_{1}(\mathrm{~B})$ & $\mathrm{DV}_{2}(\mathrm{C})$ & $\mathrm{DV}_{3}(\mathrm{~A})$ & $\mathrm{DV}_{4}(\mathrm{D})$ & IMD (C) & IMD(B) & $\operatorname{IMD}(\mathrm{A})$ & $\operatorname{IMD}(\mathrm{D})$ & $\operatorname{LIV}(\mathrm{A})$ & $\operatorname{LIV}(B)$ \\
\hline & & & & & & & & & \\
\hline \multirow[t]{2}{*}{2.1} & 3.4 & 3.4 & 4.2 & 1.74 & 2.98 & 3.6 & 4.68 & 3 & 4.4 \\
\hline & 2.84 & 3.5 & 4.1 & 1.7 & 2.9 & 3.5 & 4.6 & 2.9 & 4.3 \\
\hline 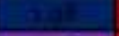 & $2 x=$ & 3.3 & 4 & 1,58 & 2.8 & 3.4 & 4.5 & 2.8 & 4.1 \\
\hline 1.8 & $3+4$ & 3 & 3.9 & 1.5 & 2.7 & 3.2 & 4.3 & 2.7 & 4 \\
\hline 1.65 & 22 & 2.86 & 3.8 & 1.4 & 3.6 & 3.1 & 4.1 & 25 & 39 \\
\hline 15 & 21 & & 3.7 & 1.28 & 25 & 3 & 4 & 23 & 3.7 \\
\hline 1.35 & & & 3.6 & 1.2 & 24 & 2.8 & 3.9 & 24 & 3.6 \\
\hline 1.2 & & & 3.54 & 0.94 & 2.3 & 2.7 & 3.7 & 2 & 3.35 \\
\hline 1.1 & & & & 0.76 & 2.2 & & 3.6 & + & 3.2 \\
\hline 0.8 & & & & 07 & 21. & & 3.5 & 2.6 & 3 \\
\hline \multirow[t]{7}{*}{0.6} & & & & & 2 & & & 1.5 & \\
\hline & & & & & 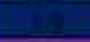 & & & 2.3 & \\
\hline & & & & & 1.2 & & & 1.25 & \\
\hline & & & & & & & & 1 & \\
\hline & & & & & & & & 0.8 & \\
\hline & & & & & & & & 0.7 & \\
\hline & & & & & & & & & \\
\hline
\end{tabular}

Table 4.1 Data Karaketristik Kontrol Valve Hingh pressure (Hp), Intermediate (Im), serta Low Pressure (Lp)

Sumber: Pltu Media Group 2014

Keterangan : 
Jurnal Mekanova

Vol 4. No. 2, April 2018

ISSN : 2502-0498

- $\mathrm{DV}=$ Kontrol Valve Hingh Pressure (HP) $\mathrm{I} \quad \mathrm{IMD}=$ Intermediate Kontrol Valve (IMD)

- $\quad$ LIV = Kontrol valve Low Pressure (LP)

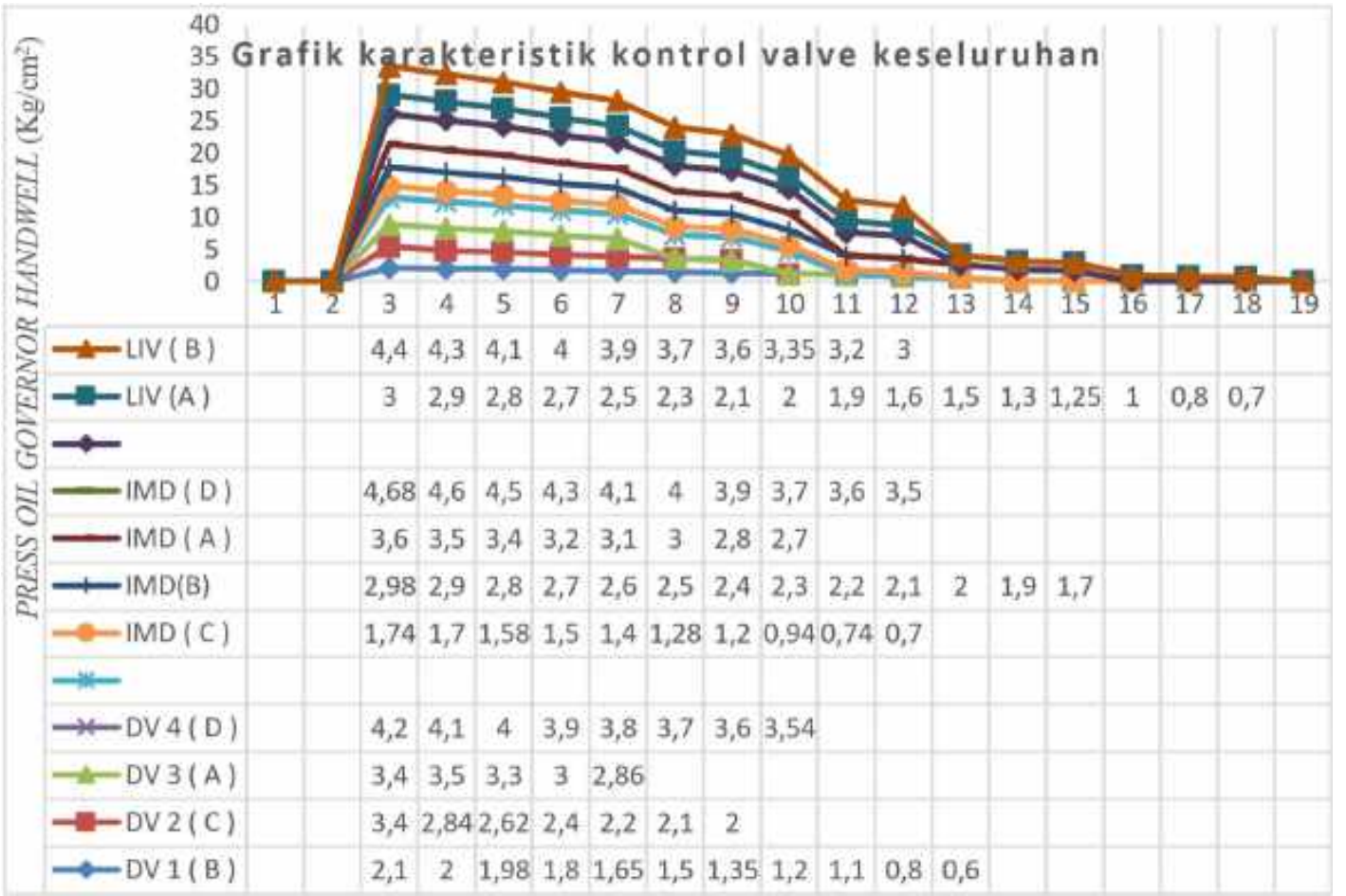

Grafik 4.6 Karakteristik kontrol valve keseluruhan

Sumber: Pltu Media Group 2014

\section{KESIMPULAN DAN SARAN}

\section{- Kesimpulan}

Kesimpulan yang dapat diambil dalam makalah ilmiah ini adalah sebagai berikut:

1. Pengaruh kinerja Kontrol valve terhadap governor terdapat dari tekanan oli yang disuplai oleh governor ketiap-tiap control valve.

2. Dimensi kontrol valve yang berkurang dapat mempengaruhi kinerja kontrol valve, dan tekanan oli dari governor kehidraulik kontrol valve.

\section{Saran}

Dikarenakan hidraulik kontrol valve telah dilakukan Overhaule maka performan dari unit tersebut berkurang, oleh karena itu untuk mengembalikan sistem operasi seperti semula, dibutuhkan waktu penyesuaian operasi.

\section{DAFTAR PUSTAKA}

1. Andrew parr, 2013, Hydrolika dan Penuematika, edisi kedua, Jakarta. 
Jurnal Mekanova

Vol 4. No. 2, April 2018

ISSN : 2502-0498

2. Manual book jerman. 1972. Turbin New Alstom Bd2eeq2e38, Nagan Raya. PT. Energy Alamraya Semesta 2014.

3. Mawardi. 2014. Laporan Kerja Major Overhaule, Nagan Raya. PT. Nusantara Turbin Dan Propulsi.

4. Nurmalita. 2012. IPB. Bogor. Analisa Efisiensi Energy Pada PLTU.

5. Divition Emerson co, Copy 1985. Brooks Instrument, Basic Hydraulies: Theory, Principle Of Operation \& Aplication.

6. Ir. Basuki, 2013. Pengaturan Daya Dan Frekuensi, Jakarta

7. Maridjo. 2013, Operational \& Maintenance CFPP Training, PT.Energi Alam raya Semesta, Nagan Raya.

8. ___ Anonim, 2012, Maintenance turbin uap, Universitas Sumatra utara.

9. Http; $\backslash \|_{w w w}$.engineeringtoolbox.com, Power plant perfonmance factor. Diakses 2015.

10. Http: |www.unep.org, United Nations environment prongramme. Diakses 2015

Lampiran 1. Dimensi ukuran Straight Bar \& Bushing Kontrol Valve

\section{Control Valve Hingh Pressure A}

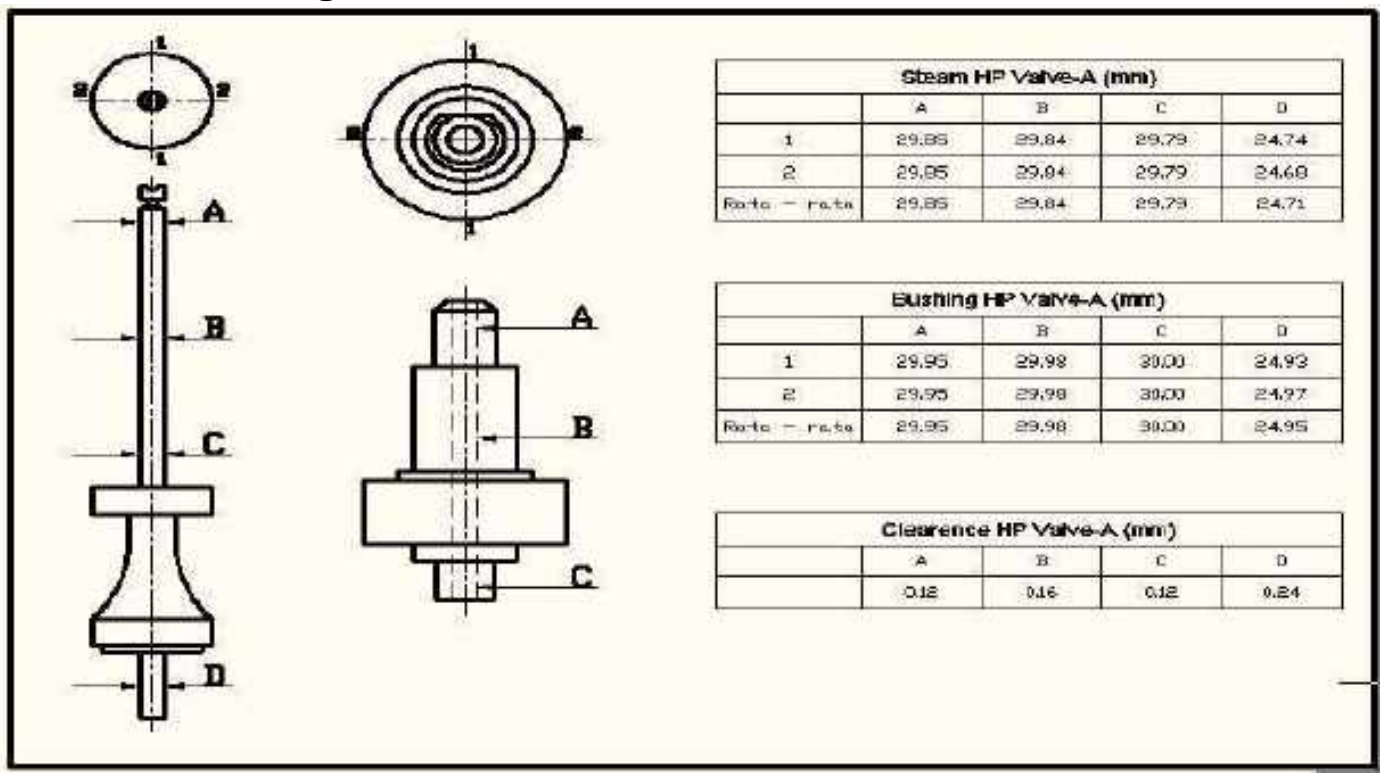


Jurnal Mekanova

Vol 4. No. 2, April 2018

ISSN : 2502-0498

Control Valve Hinh Pressure B

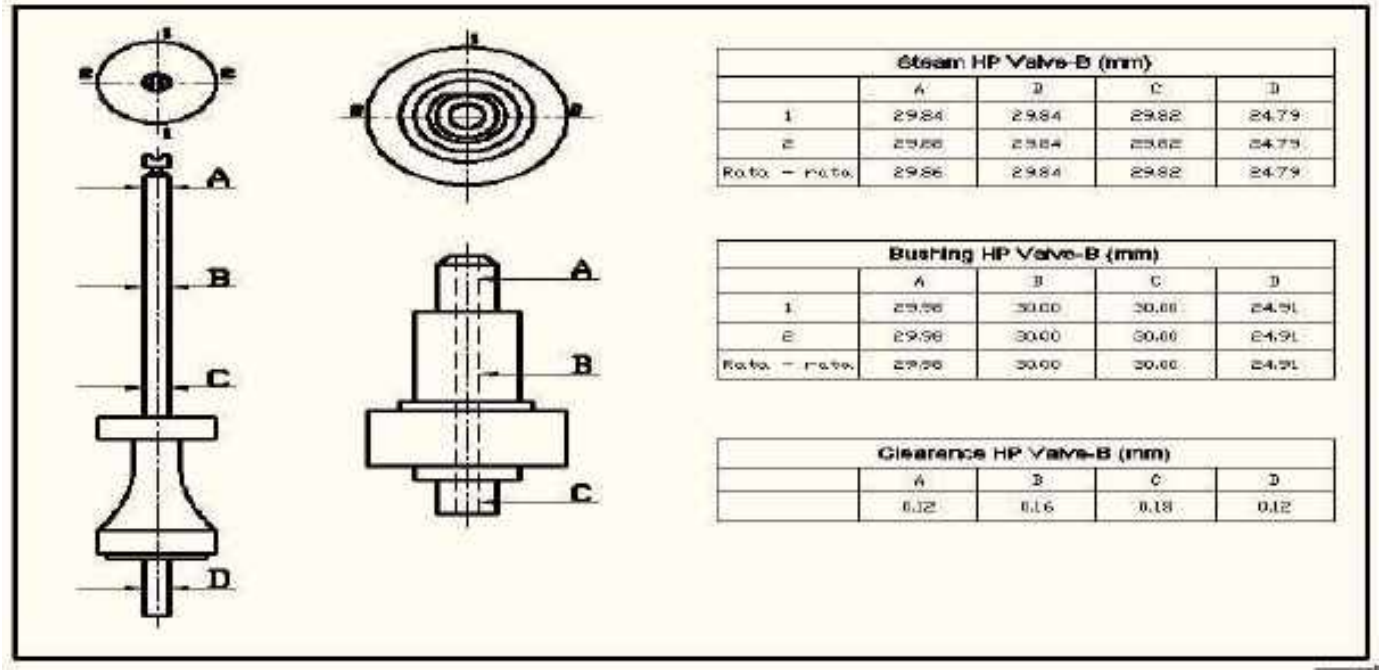

Control Valve High Presure C

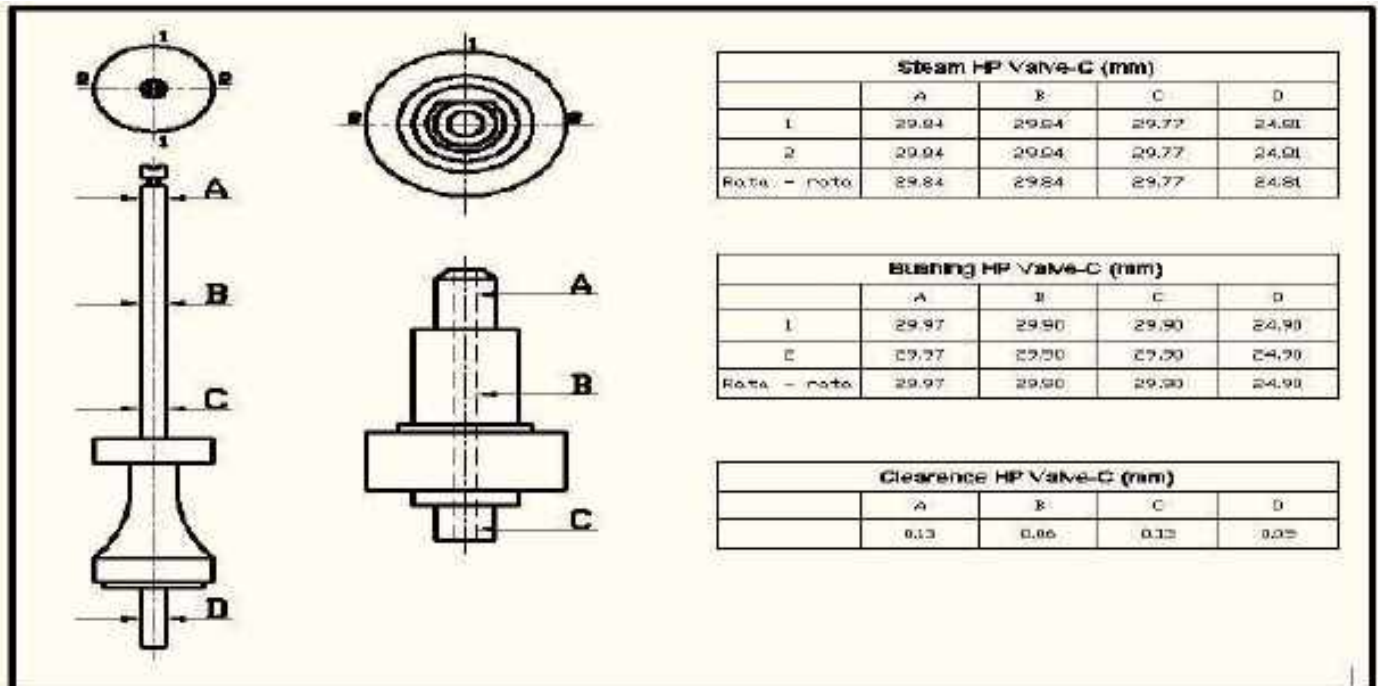


Jurnal Mekanova

Vol 4. No. 2, April 2018

ISSN : 2502-0498

\section{Control Valve High Presure D}

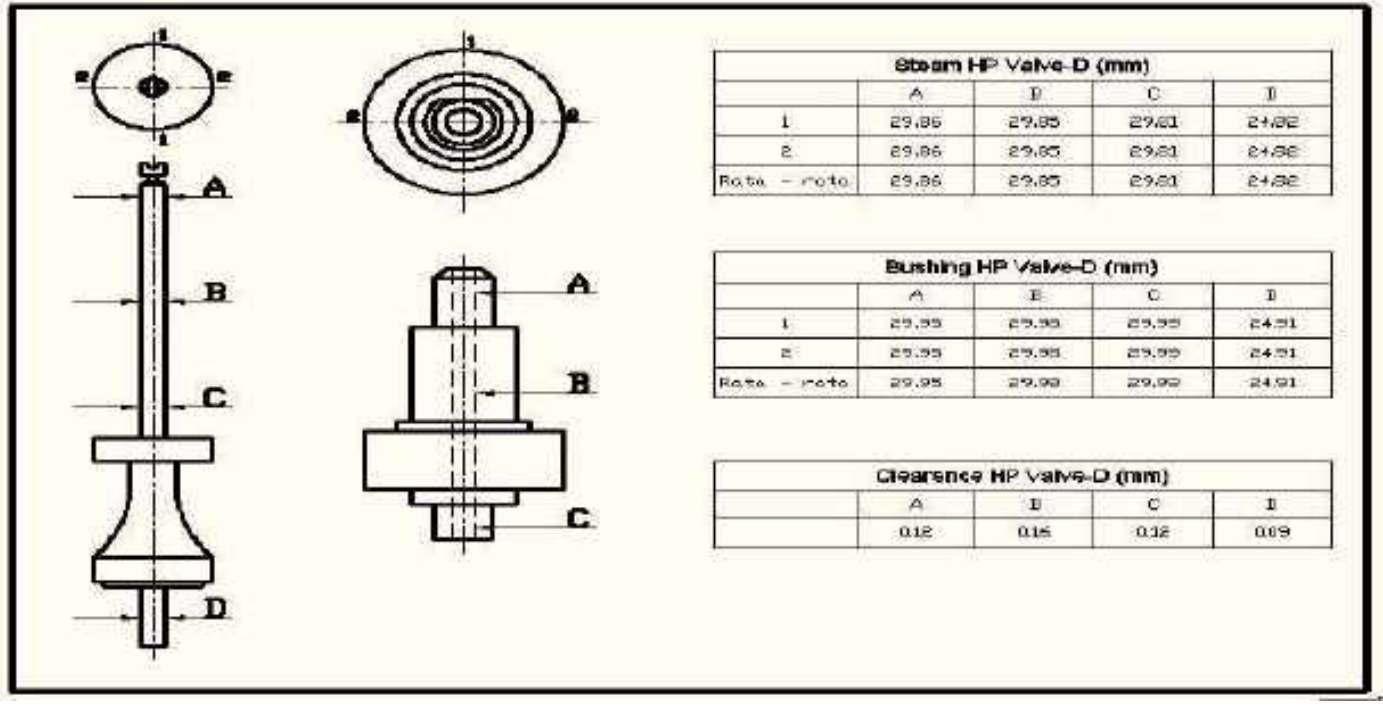

Control Valve Intermediate A

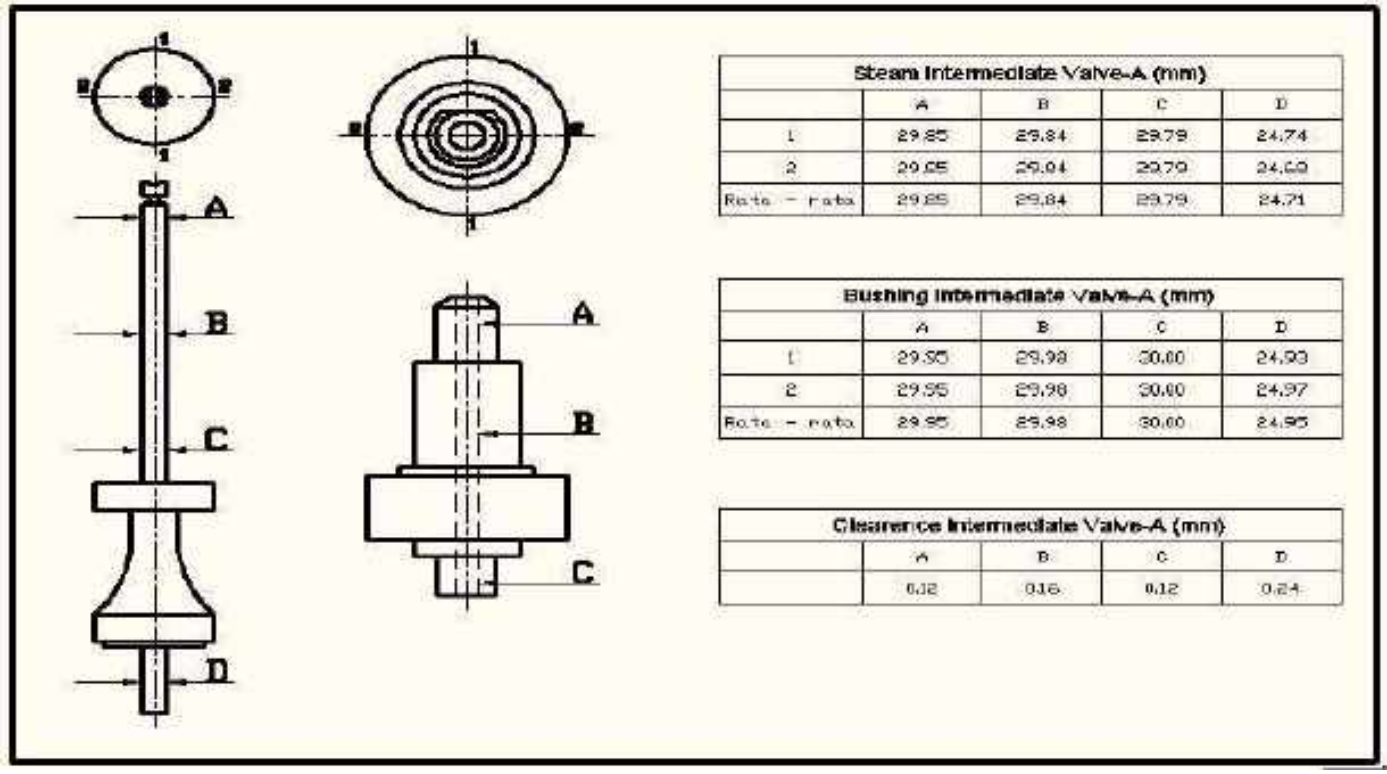


Jurnal Mekanova

Vol 4. No. 2, April 2018

ISSN : 2502-0498

Control Valve Intermediate B

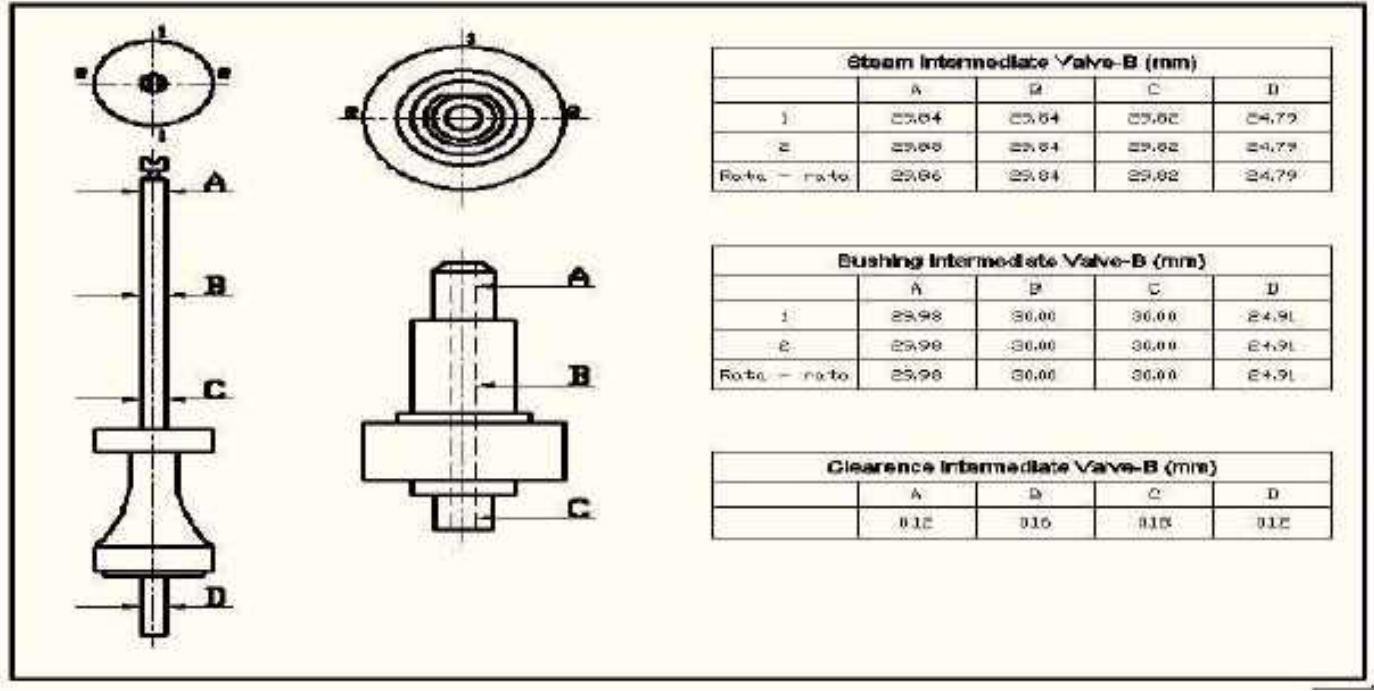

Control Valve Intermediate C

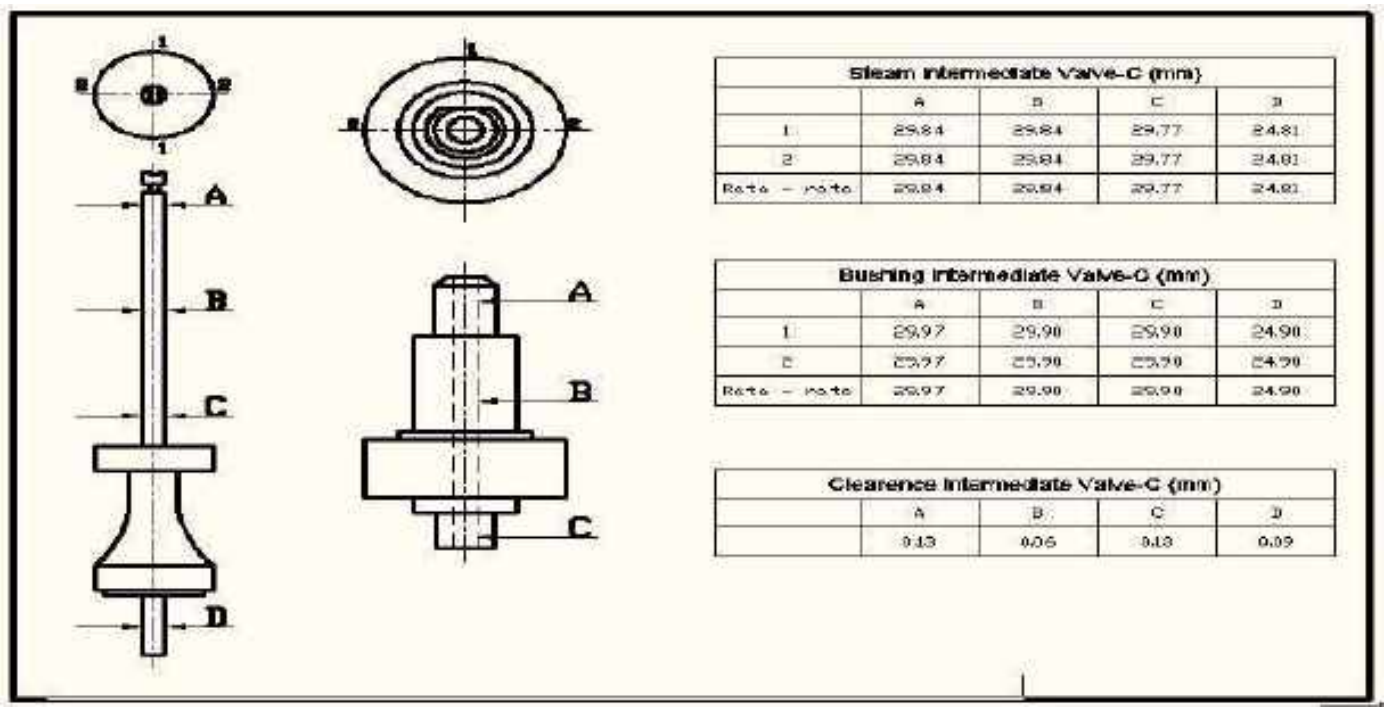


Jurnal Mekanova

Vol 4. No. 2, April 2018

ISSN : 2502-0498

\section{Control Valve Intermediate D}

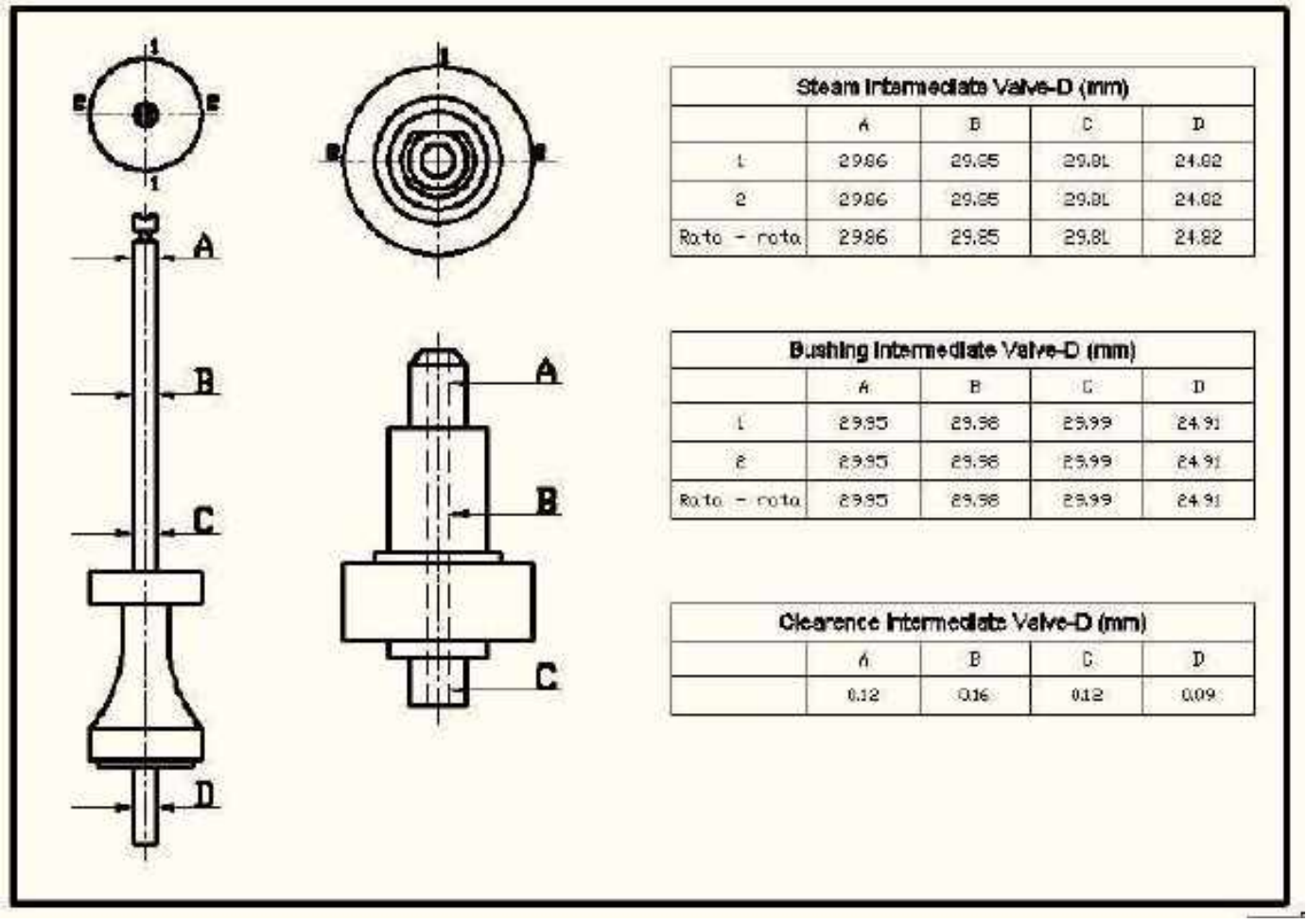

Control Valve Low Presure A

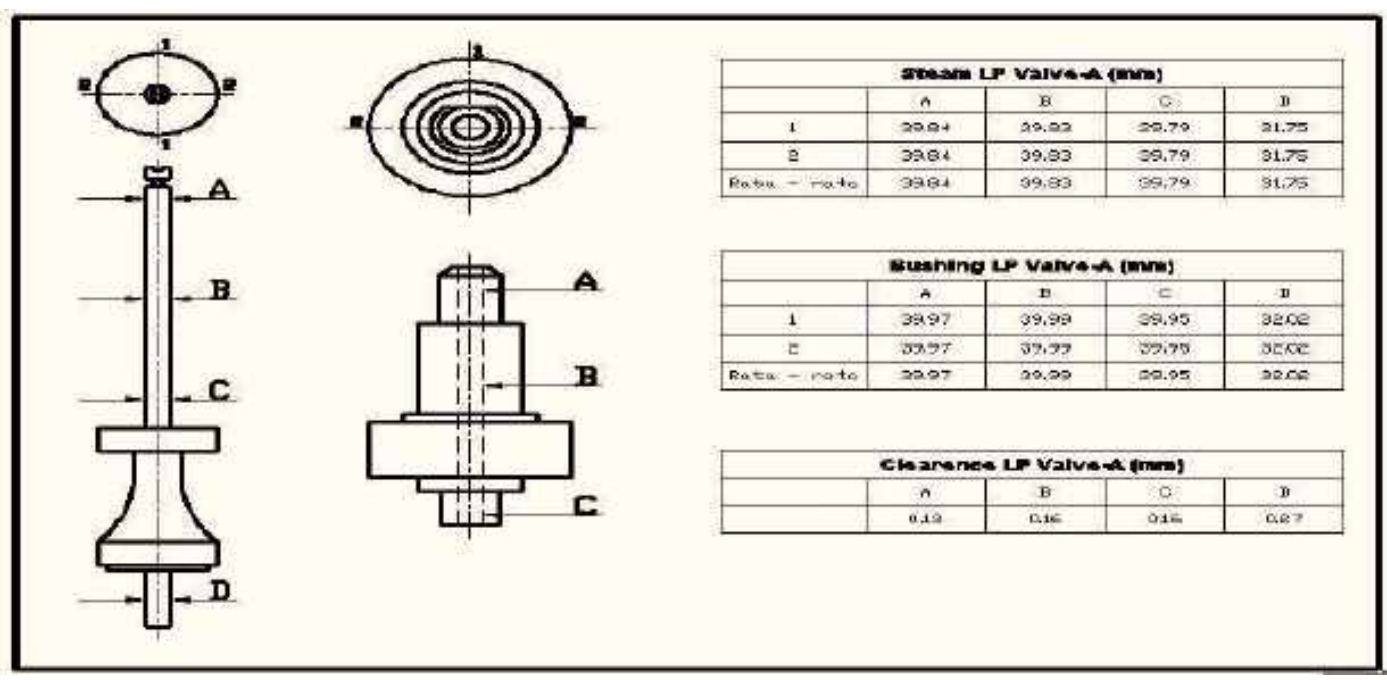


Jurnal Mekanova

Vol 4. No. 2, April 2018

ISSN : 2502-0498

\section{Control Valve Low Presure B}

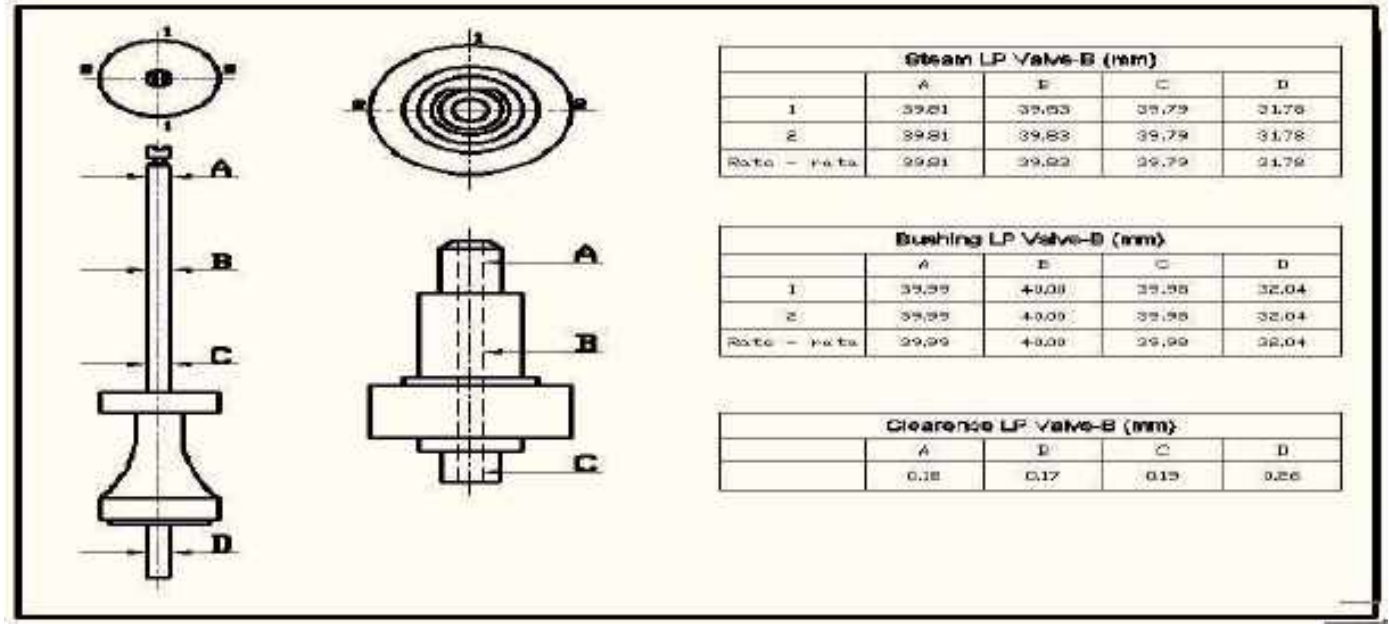

Lampiran 2. Gambar sketsa hindraulik kontrol valve 
Jurnal Mekanova

Vol 4. No. 2, April 2018

ISSN : 2502-0498

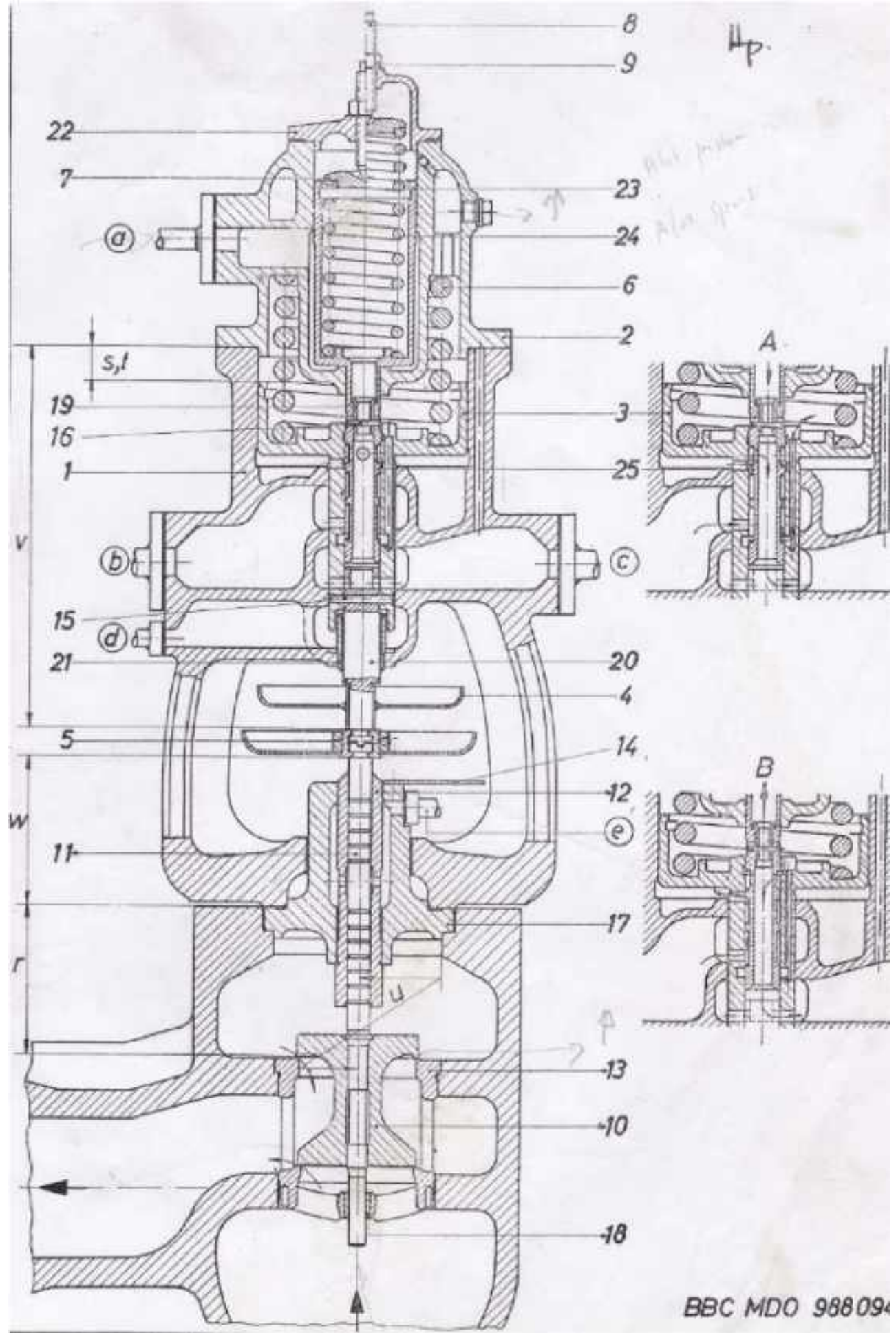

